DOI: https://doi.org/10.31933/dijms.v3i3 Received: 12 November 2021, Revised: 25 December 2021, Publish: 15 January 2022

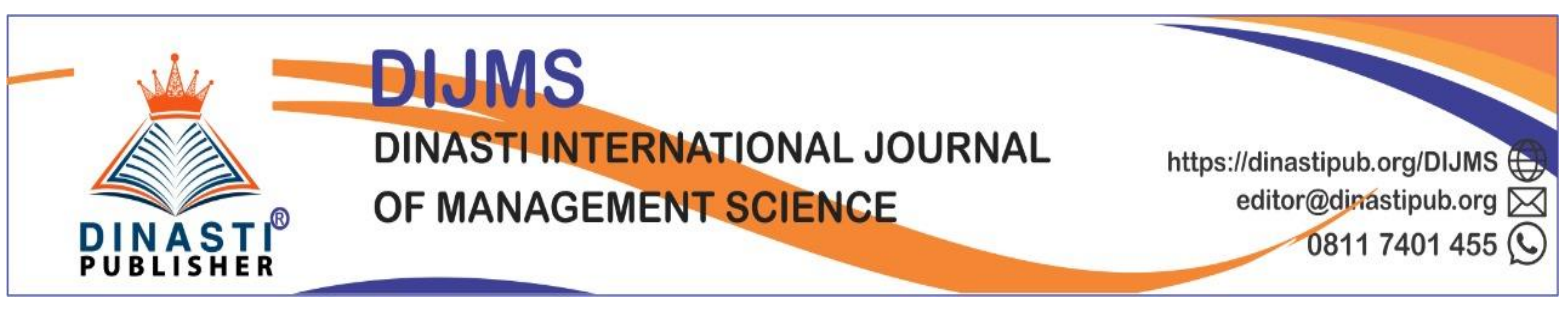

\title{
LEVEL OF UNDERSTANDING AND READINESS OF ACADEMIC COMMUNITY IN MBKM IMPLEMENTATION AT MUHAMMADIYAH UNIVERSITY OF JAKARTA
}

\author{
Herwina Bahar' ${ }^{1}$, Nuraeni Nuraeni ${ }^{2}$, Ismah Ismah ${ }^{3}$, Venni Herli, Aby $\mathbf{M}^{5}$, Hastri \\ Rosiyanti $^{6}$, Anis Setiyanti ${ }^{7}$, Lidiyatul Izzah $^{8}$, Nurbaiti Widyasari ${ }^{9}$ \\ ${ }^{1)}$ Universitas Muhammadiyah Jakarta, wina_bahar@yahoo.com \\ ${ }^{2)}$ Universitas Muhammadiyah Jakarta, nur.aini@umj.ac.id \\ ${ }^{3)}$ Universitas Muhammadiyah Jakarta, ismah.fr@gmail.com \\ ${ }^{4)}$ Universitas Muhammadiyah Jakarta \\ ${ }^{5)}$ Universitas Muhammadiyah Jakarta \\ 6)Universitas Muhammadiyah Jakarta, hastrirosiyanti@gmail.com \\ ${ }^{7)}$ Universitas Muhammadiyah Jakarta \\ ${ }^{8)}$ Universitas Muhammadiyah Jakarta \\ ${ }^{9}$ Universitas Muhammadiyah Jakarta
}

Corresponding Author: Nuraeni Nuraeni

\begin{abstract}
The purpose of this research is to find out the level of understanding and readiness of the academic community of the University of Muhammadiyah Jakarta in the implementation of the Merdeka Belajar Kampus Merdeka (MBKM) program. The research method used is quantitative derivative, the object of research/respondents who are sampled are lecturers, students, and education personnel. Data retrieval technique by filling out questionnaires through SpadaDikti survey link. The results of the analysis of questionnaire data are interpreted in the form of percentages of each answer given by respondents. The results of this research can be a reference material for further research, in the implementation of the MBKM Program implemented at the University of Muhammadiyah Jakarta, so that it is expected to improve and improve the performance of the Merdeka Belajar Kampus Merdeka (MBKM) program.
\end{abstract}

Keywords: Merdeka Belajar Kampus Merdeka, Academic Community

\section{INTRODUCTION}

Merdeka Belajar Kampus Merdeka (MBKM) program is one of the breakthroughs of the Ministry of Education, Culture, Research and Technology in spurring quality and characterful human resources, because through the program launched, it is expected that both students and lecturers have different experiences that will ultimately enrich insight, network, and character excellence. The MBKM program is implicitly the response of kemdikburistek to prepare resilient graduates in the face of social, cultural, the world of work, and technology 
changes that are increasing in the era of industrial revolution 4.0, student competence must be further strengthened by existing developments. There is a need for a link and match between higher education graduates with the business world and the industrial world and a future that is increasingly changing.

The success of universities in implementing government policies in welcoming Indonesia Gold is by implementing an adaptive curriculum and being able to adapt to the times. Based on this, the Ministry of Education and Culture has enacted a new policy in higher education through the program "Merdeka Belajar Kampus Merdeka (MBKM)," which is currently being implemented by universities. The Ministry of Education's approach provides freedom for students to participate in learning activities for a maximum of three semesters of study outside of their study programs and campuses.

Mbkm policy provides opportunities for students to gain a broader learning experience and new competencies through learning activities, including student exchange, internship/work practices, research, independent projects, entrepreneurial activities, humanitarian projects, teaching in schools, and projects in villages / actual work lectures. In addition, students are also given the freedom to participate in learning activities outside their study program inside the same college with a certain credit weight. Students can carry out all these activities with the guidance of lecturers, and a cooperation agreement is needed if done with parties outside the Study Program. They are implementing MBKM through partnership and cooperation programs between universities both at home and abroad to improve the competence of lecturers and students. Even in the MBKM Guidebook, it is said that cooperation with partners will also involve lecturers in mentoring and academic activities to improve their competence. Learning innovation is also a case to equip students with problem-solving skills, critical thinking, collaboration, communication, and caring through various innovative learning methods, including case-solving and project-based learning. The direction of curriculum development and the choice of cooperation partners for the implementation of MBKM are also considerations of study programs in preparing their accreditation both nationally and internationally.

The key to successfully implementing MBKM policy in a college is the courage to change the mindset from a rigid content-based curriculum approach to an adaptive and flexible learning achievement-based curriculum to prepare students to become independent adults. The Study Program is challenged in developing an adaptive curriculum. It can adapt to the rapid development of the times without reaching the goal of producing graduates according to predetermined learning achievements. In addition, in implementing MBKM policy, collaboration and cooperation with partners or other parties related to the scientific field and participate in supporting the desired learning achievements. While the University of Muhammadiyah, in supporting the MBKM program, has made several efforts, both in the preparation and implementation stages. Since 2020 Muhammadiyah University of Jakarta (UMJ) has been lent to the MBKM curriculum. This is done to succeed Indonesia Gold 2045 by having the goal of qualified student graduates in terms of rational, critical, active, innovative, nationally minded. Entrepreneur mindset produces graduates who are always true learners who are competent, flexible, and resilient (agile learner), ready to contribute positively to nation- 
building and become productive world citizens.

To improve the quality and curriculum in the learning process is directed using a problem-solving approach (case method) and project-based learning that focuses on student center learning that is in harmony with IKU 7, which is a collaborative learning activity to provide an authentic experience to students, in the hope that students can get a better learning experience which of course this process is supported by the government.

The government continues to increase the relevance of higher education to the problems and needs in the global community to prepare human resources in welcoming Indonesia Gold 2045. Many things have been done by the government, starting from creating higher education transformations controlled through the Merdeka Belajar: Merdeka Campus policy, a system that encourages campus flexibility in collaboration with the business world, the industrial world, and the general public. Further supporting the process, the government issued a policy through the Decree of the Minister of Education and Culture No. 3/M/2021 on Key Performance Indicators (IKU) of State Universities and Higher Education Service Institutions in the Ministry of Education and Culture. The purpose of this research is to find out the extent of the level of understanding and readiness of the academic community of the University of Muhammadiyah Jakarta in the implementation of Merdeka Belajar Kampus Merdeka.

\section{LITERATURE REVIEW}

Merdeka campus becomes a new concept that allows students to get the independence to study in college (level, 2020; Muhsin, 2021; Wijayanto, 2021). This concept is a continuation of the previous idea of Merdeka Belajar. Planning the view of Merdeka Campus is a learning innovation to get quality learning quality.

The Legal Basis for the implementation of the MBKM curriculum (Merdeka Belajar Kampus Merdeka) is Permendikbud Number 3 of 2020 on Higher Education standards; Permendikbud No. 4 of 2020 on The Change of State Universities into Incorporated Universities; Permendikbud No. 5 of 2020 on Accreditation of Study Programs and Universities; Permendikbud No. 6 of 2020 concerning the Admission of New Students study program at state universities; Decree No. 7 of 2020 on Establishment, Change, Dissolution of State Universities, and Establishment, Change, Revocation of Private College Permits.

The purpose of Merdeka Belajar Kampus Merdeka policy is to encourage students to master various fields of science by their fields of expertise so that they are ready to compete in the global world (Baharuddin, 2021; Fatmawati, 2020; Tohir, 2020). This policy allows students to choose the courses they will take based on their wishes.

\section{RESEARCH METHOD}

The method used in this study is a quantitative description which provides an overview of the phenomena and literature studies in the form of information collected from several sources, namely the internet, journals, and books. The purpose is to obtain deeper information and analyze the academic community's understanding of the Merdeka Belajar-Kampus 
Merdeka (MBKM) program. Data collection technique using questionnaires/questionnaires through SpadaDikti survey link at the academic community of Muhammadiyah University of Jakarta, namely Lecturers, Students, and Education Personnel.

\section{FINDINGS AND DISCUSSION}

In this study, the targets of respondents who want to be achieved by the University of Muhammadiyah Jakarta are as follows:

Table 1 Respondent

\begin{tabular}{|l|l|l|}
\hline \multicolumn{1}{c|}{ Target } & \multicolumn{1}{c|}{ Population } & \multicolumn{1}{c|}{ Sample } \\
\hline Lecturer & 596 Lecturer & $306(21,58 \%$ \\
\hline Student & 21.021 Student & $4537(51,34 \%)$ \\
\hline Education Energy & 637 Tendik & $307(49,76 \%)$ \\
\hline
\end{tabular}

Due to time and effort constraints, the respondent's target could not be met, so the research team used the sample data obtained. Data from the measurement of the academic community's level of understanding and readiness in the implementation of Merdeka Belajar Kampus Merdeka (MBKM), recapitulation of data first by separating answers from question items with open questions and closed forms. Question items with closed-form answers will be carried out in the coding process (coding) to change qualitative data to quantitative with a nominal scale to facilitate the analysis process.

Based on the results of the survey and data processing of samples obtained related to the level of understanding and readiness of the academic community in the implementation of MBKM through the SpadaDikti Survey Link descriptively can be seen in Table 2 below:

Table 2 Questionnaire 1 SPADA Dikti

\begin{tabular}{|c|c|c|c|c|c|c|c|}
\hline \multirow{2}{*}{ Pertanyaan } & \multirow{2}{*}{ Jawaban } & \multicolumn{2}{|c|}{ Mahasiswa } & \multicolumn{2}{|c|}{ Dosen } & \multicolumn{2}{|c|}{ Tendilk } \\
\hline & & Count & Percent & Count & Percent & Count & Percent \\
\hline \multirow{4}{*}{$\begin{array}{l}\text { Seberapa jauh Saudara mengetahui } \\
\text { tentang kebijakan Merdeka Belajar- } \\
\text { Kampus Merdeka (MBKM)? }\end{array}$} & $\begin{array}{l}\text { Mengetahui kebijakan secara } \\
\text { keseluruhan. }\end{array}$ & 184 & $4.06 \%$ & 55 & $17.97 \%$ & 20 & $6.31 \%$ \\
\hline & $\begin{array}{l}\text { Mengetahui sebagian besar isi } \\
\text { kebijakannya. }\end{array}$ & 2096 & $46.20 \%$ & 181 & $59.15 \%$ & 216 & $68.14 \%$ \\
\hline & Mengetahui sedikit. & 1714 & $37.78 \%$ & 66 & $21.57 \%$ & 60 & $18.93 \%$ \\
\hline & Belum mengetahui sama sekali. & 543 & $11.97 \%$ & 4 & $1.31 \%$ & 21 & $6.62 \%$ \\
\hline \multicolumn{2}{|c|}{ TOTAL } & 4537 & $100.00 \%$ & 306 & $100.00 \%$ & 317 & $100.00 \%$ \\
\hline
\end{tabular}

Based on Table 2, it is seen that each respondent's answer to the question item "How far do you know about the Merdeka Belajar Kampus Merdeka (MBKM) policy? Respondents who 
answered knew the overall policy, of the 306 lecturers who answered 55 people or about $17.97 \%$, students who responded about $4.06 \%$ were 184 people out of 4,537 . At the same time, the education force is about 20 people $(6.31 \%)$. On the one hand, there are still many lecturers $(59.15 \%)$, students $(46.20 \%)$, and education personnel (68.14\%) who answer knowing most of the contents of their policies. Answering knows a little, lecturers (37.78\%), students $(21.5 \%)$, education personnel (18.93\%). At the same time, respondents who did not understand were 4 lecturers $(1.31 \%), 543$ students $(11.97 \%)$, and $6.62 \%$ or 21 education personnel. Respondents' answers to the question item in question can be seen in graph 1.

\section{Graph 1}

Questionnaire 1 SpadaDikt

How far do you know about the Merdeka Belajar-Kampus Merdeka (MBKM) policy?

\section{Student $\quad \square$ Lecture $\square$ Tendik}

68,14

$\%$

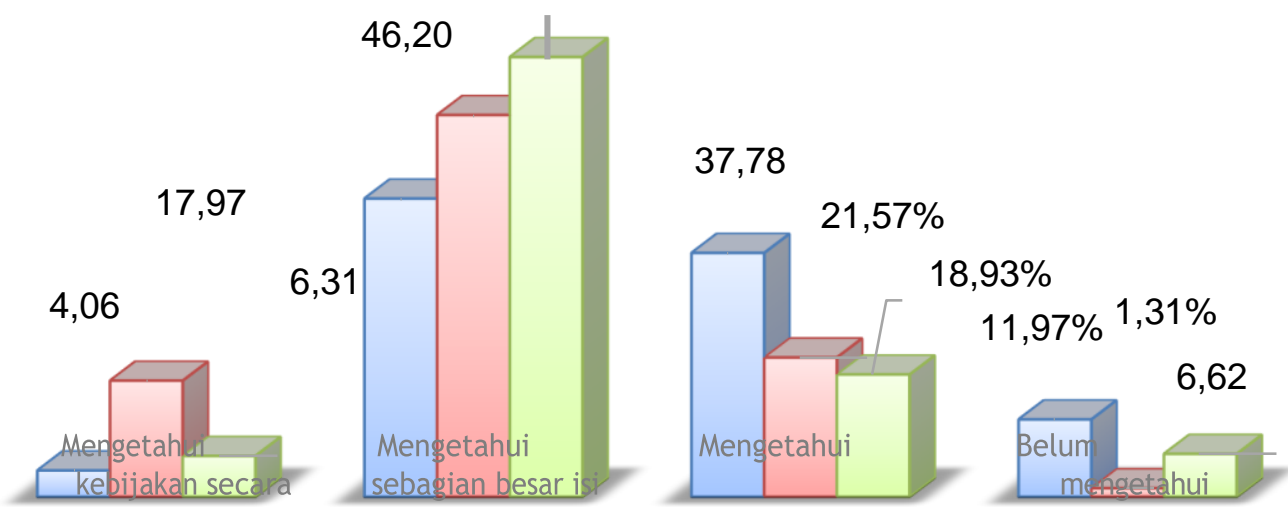

Table 3

Questionnaire 2 SpadaDikti

\begin{tabular}{|c|c|c|c|c|c|c|c|}
\hline \multirow{2}{*}{ Pertanyaan } & \multirow{2}{*}{ Jawaban } & \multicolumn{2}{|c|}{ Mahasiswa } & \multicolumn{2}{|c|}{ Dosen } & \multicolumn{2}{|c|}{ Tendik } \\
\hline & & Count & Percent & Count & Percent & Count & Percent \\
\hline \multirow{4}{*}{$\begin{array}{c}\text { Menurut Saudara, hingga berapa semester } \\
\text { dan berapa sks yang dapat disetarakan } \\
\text { dengan bentuk kegiatan MBKM di luar } \\
\text { Perguruan Tingginya? }\end{array}$} & 1 & 263 & $6.58 \%$ & 19 & $6.29 \%$ & 6 & $2.03 \%$ \\
\hline & 2 & 2044 & $51.18 \%$ & 154 & $50.99 \%$ & 221 & $74.66 \%$ \\
\hline & 3 & 878 & $21.98 \%$ & 103 & $34.11 \%$ & 43 & $14.53 \%$ \\
\hline & 4 & 809 & $20.26 \%$ & 26 & $8.61 \%$ & 26 & $8.78 \%$ \\
\hline \multicolumn{2}{|c|}{ TOTAL } & 3994 & $100.00 \%$ & 302 & $100.00 \%$ & 296 & $100.00 \%$ \\
\hline
\end{tabular}

Based on table 3, it can be seen that most answered no. 2,154 lecturers (50.99\%), 
$51.18 \%$ of students (2044 people) and education personnel 221 people (74.66\%). This shows that more than $50 \%$ of the academic community knows Permendikbud No. 3 of 2020, regarding 2 semesters that can be equated with MBKM activities outside of Higher Education. More details can be seen in graph 2 .

\section{Graph 2 Questionnaire 2 SpadaDikti}

According to you, how many semesters and how many credits can be equated with the form of MBKM activities outside of his

College?

\section{Mahasiswa $\square$ Dosen $\square$ Tendik}

\section{$74,66 \%$}

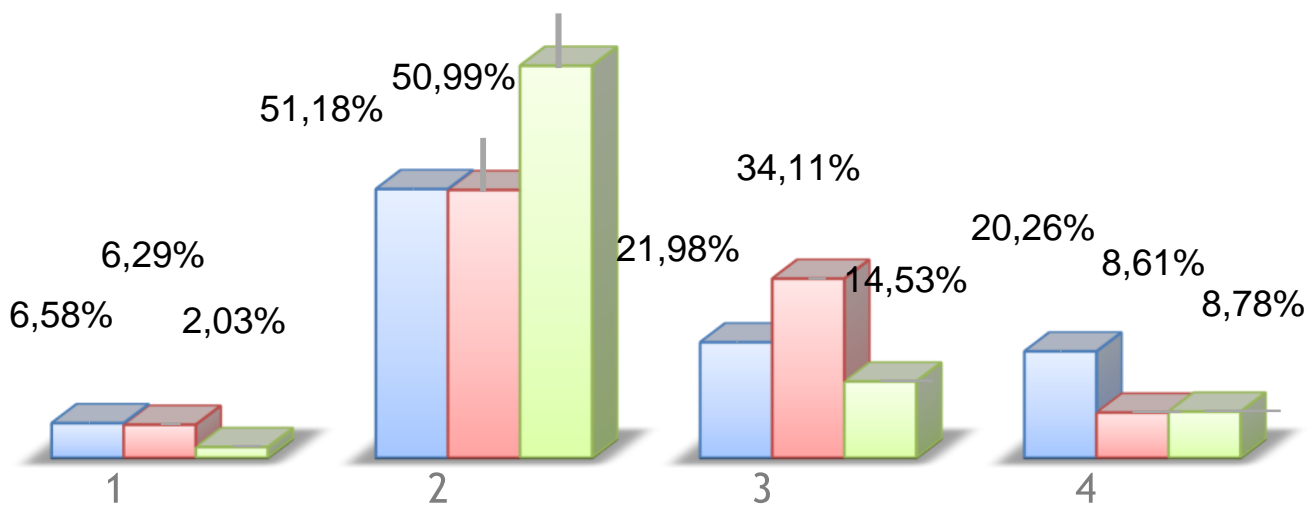

Table 4

Questionnaire 4 SpadaDikti

\begin{tabular}{|c|c|c|c|c|c|c|c|}
\hline \multirow{2}{*}{ Pertanyaan } & \multirow{2}{*}{ Jawaban } & \multicolumn{2}{|c|}{ Mahasiswa } & \multicolumn{2}{|c|}{ Dosen } & \multicolumn{2}{|c|}{ Tendllk } \\
\hline & & Count & Percent & Count & Percent & Count & Percent \\
\hline \multirow{7}{*}{$\begin{array}{l}\text { Dari mana Saudara mendapat informasi } \\
\text { mengenai kebijakan Merdeka Belajar- } \\
\text { Kampus Merdeka (MBKM)? }\end{array}$} & $\begin{array}{l}\text { Kanal daring Kemendikbud (laman/website, } \\
\text { media sosial). }\end{array}$ & 692 & $17.33 \%$ & 31 & $10.26 \%$ & 17 & $5.74 \%$ \\
\hline & $\begin{array}{l}\text { Kegiatan sosialisasi luring/daring yang } \\
\text { diselenggarakan oleh Kemendikbud. }\end{array}$ & 175 & $4.38 \%$ & 41 & $13.58 \%$ & 12 & $4.05 \%$ \\
\hline & $\begin{array}{l}\text { Kanal daring Perguruan Tinggi (laman/website, } \\
\text { media sosial). }\end{array}$ & 615 & $15.40 \%$ & 28 & $9.27 \%$ & 17 & $5.74 \%$ \\
\hline & $\begin{array}{l}\text { Kegiatan sosialisasi luring/daring yang } \\
\text { diselenggarakan oleh Perguruan Tinggi. }\end{array}$ & 1740 & $43.57 \%$ & 167 & $55.30 \%$ & 227 & $76.69 \%$ \\
\hline & $\begin{array}{l}\text { Kanal komunikasi komunitas (misal: komunitas } \\
\text { alumni, komunitas dosen). }\end{array}$ & 193 & $4.83 \%$ & 14 & $4.64 \%$ & 3 & $1.01 \%$ \\
\hline & Media massa. & 502 & $12.57 \%$ & 16 & $5.30 \%$ & 16 & $5.41 \%$ \\
\hline & Lainnya: & 77 & $1.93 \%$ & 5 & $1.66 \%$ & 4 & $1.35 \%$ \\
\hline & TOTAL & 3994 & $100.00 \%$ & 302 & $100.00 \%$ & 296 & $100.00 \%$ \\
\hline
\end{tabular}

In table 4, with the question "Where do you get information about the policy of Merdeka Belajar Kampus Merdeka (MBKM)? 55.30\% (167 lecturers), 43.57\% (1740 students) and 227 (76.69\%) education personnel answered offline / online socialization activities held by universities. The information obtained by each respondent scatters the rest. 


\section{Graph 3}

Questionnaire 4 SpadaDikti

Where do you get information about the Merdeka Belajar-Kampus Merdeka (MBKM) policy?
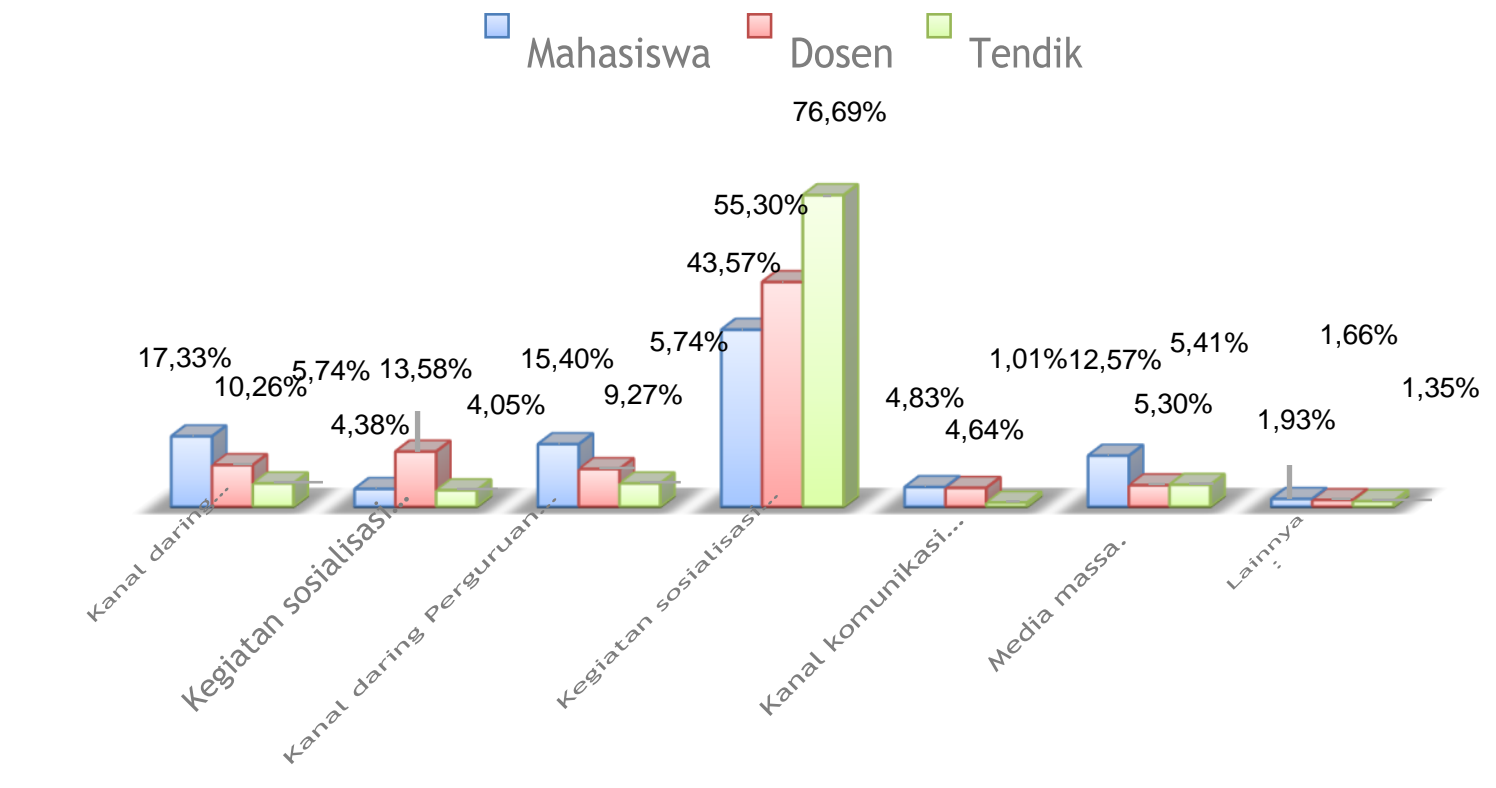

Table 5

Questionnaire 6 SpadaDikti

\begin{tabular}{|c|c|c|c|c|c|c|c|}
\hline \multirow{2}{*}{ Pertanyaan } & \multirow{2}{*}{ Jawaban } & \multicolumn{2}{|c|}{ Mahosiswa } & \multicolumn{2}{|c|}{ Dosen } & \multicolumn{2}{|c|}{ Tendllk } \\
\hline & & Count & Percent & Count & Percent & Count & Percent \\
\hline $\begin{array}{c}\text { Apakah Program Studi Saudara mempunyail } \\
\text { program terdahulu yang sesuai dengan }\end{array}$ & $Y_{a}$ & 3154 & $78.97 \%$ & 237 & $78.48 \%$ & 246 & $83.11 \%$ \\
\hline $\begin{array}{c}\text { bentuk kegiatan Merdeka Belajar-Kampus } \\
\text { Merdeka (MBKM)? }\end{array}$ & Tidak & 840 & $21.03 \%$ & 65 & $21.52 \%$ & 50 & $16.89 \%$ \\
\hline $\mathrm{TO}$ & & 3994 & $100.00 \%$ & 302 & $100.00 \%$ & 296 & $100.00 \%$ \\
\hline
\end{tabular}

In table 5, More than 75\%, the academic community answered "Yes" with the question "Does the Brother Study Program have a previous program that is in the form of Merdeka Belajar Kampus Merdeka (MBKM) activities? 237 lecturers (78.48\%), 3154 students (78.97\%) and education personnel $83.11 \%$ or 246 people. 


\section{Graph 4 \\ Questionnaire 6 SpadaDikti}

Does the Brother Study Program have a previous program that is in accordance with the form of Merdeka Belajar-Kampus Merdeka

(MBKM) activities?

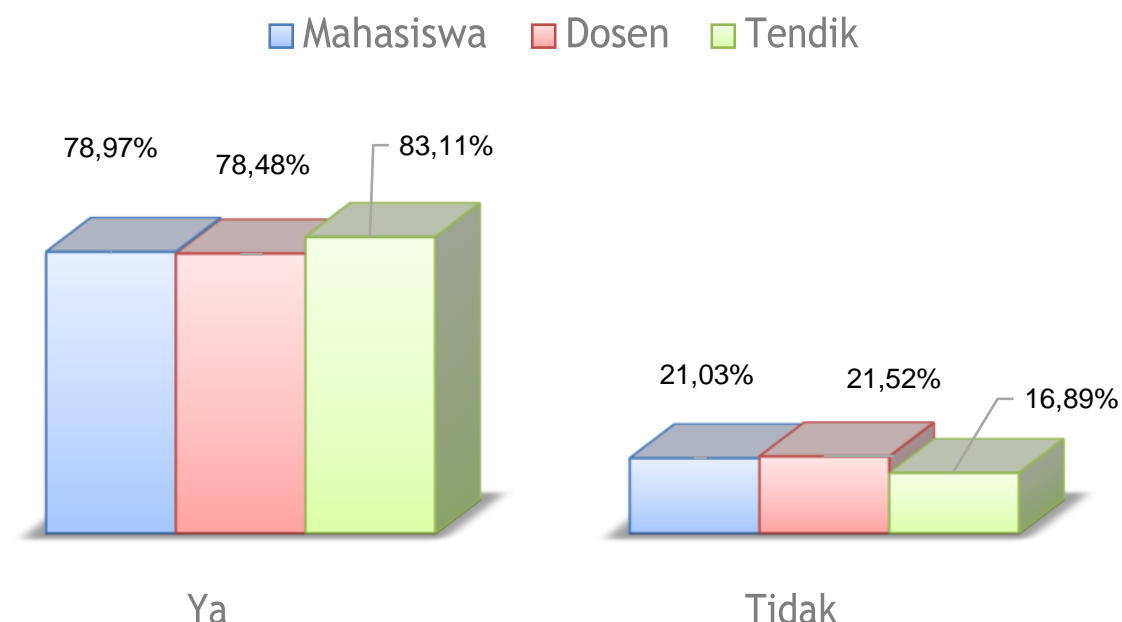

\section{CONCLUSION}

Based on the results of respondents' questionnaire answers, it can be concluded that most academicians are quite understanding and ready to implement the Merdeka Belajar Kampus Merdeka program. Therefore, similar activities can be applied in universities to increase knowledge and understanding of the academic community related to Merdeka Belajar Kampus Merdeka implementation. It can run optimally by the expectations of the Ministry of Education, Culture, Research, and Technology of the Republic of Indonesia.

Thank you to the Directorate General of Higher Education, Research and Technology of the Ministry of Education, Culture, Research and Technology for the assistance of Funding Independent Policy Research on Independent Campus Learning and Community Service Based on Research Results and PTS Prototypes. Next, thank you to the Rector and Chairman of the Institute of Research and Community Service (LPPM) at the University of Muhammadiyah Jakarta.

\section{BIBLIOGRAPHY}

Baharuddin, M. R. (2021). Adaptasi Kurikulum Merdeka Belajar Kampus Merdeka (Fokus: Model MBKM Program Studi). Jurnal Studi Guru dan Pembelajaran, 4(1), 195-205. https://e-journal.my.id/jsgp/article/view/591 
Dewi Wulandari, dkk, (2021) Panduan Program Bantuan Kerjasama Kurikulum dan Implementasi Merdeka Belajar Kampus Merdeka, Direktorat Pembelajaran dan Kemahasiswaan Dirjen Dikti Kementerian Pendidikan, Kebudayaan, Riset dan Teknlogi, Jakarta, hlm. 1-12. Diakses dari

https://dikti.kemdikbud.go.id/wp- $\quad$ content/uploads/2021/02/PanduanKerjasama-Kurikulum-dan-Implementasi-MBKM- Tahun-2021-Final.pdf

Fatmawati, E. (2020). Dukungan Perpustakaan Dalam Implementasi "Kampus Merdeka Dan Merdeka Belajar.” Jurnal Pustaka Ilmiah, 6(2), 1076-1087. https://doi.org/10.20961/jpi.v6i2.46682

Leuwol, N. V., Wula, P., Purba, B., Marzuki, I., Brata, D. P. N., Efendi, M. Y., Masrul, M., Sahri, S., Ahdiyat, M., \& Sari, I. N. (2020). Pengembangan Sumber Daya Manusia Perguruan Tinggi: Sebuah Konsep, Fakta dan Gagasan. Medan: Yayasan Kita Menulis.

Muhsin, H. (2021). Kampus Merdeka Di Era New Normal. Dalam: A. Muslihat dkk. Masa Depan Kampus Merdeka \& Merdeka Belajar: Sebuah Bunga Rampai Dosen. 143. Bintang Visitama Publisher.

Rodiyah Rodiyah, (2021), Implementasi Program Merdeka Belajar Kampus Merdeka Seminar Nasional Hukum Universitas Negeri Semarang, 7(2)

Suwandi, S. (2020). Pengembangan Kurikulum Program Studi Pendidikan Bahasa (dan Sastra) Indonesia yang Responsif terhadap Kebijakan Merdeka Belajar-Kampus Merdeka dan Kebutuhan Pembelajaran Abad ke-21. Dalam: Prosiding Seminar Daring Nasional: Pengembangan Kurikulum Merdeka Belajar Program Studi Pendidikan Bahasa Indonesia, , pp 1-12. https://ejournal.unib.ac.id/index.php/semiba/article/view/13356

Tohir, M. (2020). Buku Panduan Merdeka Belajar-Kampus Merdeka. Wijayanto, A. (2021). Implementasi dan Problematika Merdeka Belajar. OSF Preprints. https://doi.org/10.31219/osf.io/yshk6 